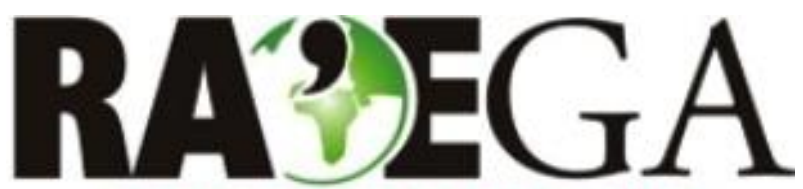

O ESPAÇO GEOGRÁFICO EM ANÁLISE

\title{
MULTITEMPORAL ANALYSIS OF SAR IMAGES FOR DETECTION OF FLOODED AREAS IN PANTANAL
}

\section{ANÁLISE MULTITEMPORAL DE IMAGENS SAR PARA DETECÇÃO DE ÁREA INUNDADAS NO PANTANAL}

\author{
Gabriel Henrique de Almeida Pereira ${ }^{1}$, Clóvis Cechim Júnior² ${ }^{2}$ Giovani Fronza ${ }^{3}$, Flávio André Cecchini \\ Deppe $^{4}$
}

\begin{abstract}
The Pantanal is one of the most important and preserved biomes in Brazil. This region is annually flooded due to episodes of precipitation along the Paraguay River and its tributaries. Understanding the dynamics of flooding is extreme important since it influences the entire Pantanal ecosystem. Remote Sensing data is an alternative to the identification of flooded areas and their changes in different periods. Among the possible sensors capable of mapping these flooded areas Radar sensor is one of the most attractive - mainly due to the low influence of cloud cover and atmospheric conditions, allowing imaging in dry or rainy seasons. For this work, Radar images from Sentinel 1 satellites for the years 2016, 2017, and 2018 were used. All available data from these years for the study area were used to generate images that represent the seasonality in the region for each year. In total, 1141 Sentinel 1 radar images were processed. The processing of such amount of data was possible through Google Earth Engine platform, which is capable of robust processing of a large amount of data, especially Remote Sensing data. At the end, it was possible to generate images that represent the seasonality of each year. It was also possible to compare the years, highlighting the differences between flooded areas indicating the periods of major precipitation.
\end{abstract}

Keywords: Remote Sensing; image processing; time series images; seasonality; wetlands.

\section{RESUMO}

O Pantanal é um dos biomas mais importantes e conservados do Brasil. Esta região é alagada anualmente em períodos chuvosos. O entendimento da dinâmica de inundação é de extrema importância, pois influencia todo o ecossistema do Pantanal. Para identificar as áreas inundadas e suas alterações em diferentes períodos anualmente, devido à grande extensão territorial do bioma, surge como alternativa o uso de dados de Sensoriamento Remoto. Dentre os possíveis sensores capazes de mapeamento destas áreas inundáveis se destaca o radar, principalmente pela baixa influência de cobertura de nuvens, permitindo imageamento em épocas de chuva ou seca, independente das condições climáticas. Desta forma, para este trabalho, utilizou-se imagens de radar do satélite Sentinel 1, para os anos de 2016, 2017 e 2018. Todos os dados disponíveis destes anos para a área de estudo foram utilizadas para geração de imagens que representam a sazonalidade na região. Ao todo, 1141 imagens de radar do Sentinel 1 foram processadas. O processamento de tal quantidade de dados foi possível a partir da plataforma Google Earth Engine, capaz de robusto processamento de grande quantidade de dados, em especial de Sensoriamento Remoto. Ao fim, foi possível gerar uma imagem que representa a sazonalidade anual, realçando a diferença de variação entre áreas alagadas que ocorre durante todo o ano.

Palavras chave: Sensoriamento Remoto; processamento de imagens; séries temporais de imagens; sazonalidade; áreas alagadas.

\footnotetext{
${ }^{1}$ Meteorological System of Paraná -(SIMEPAR), Curitiba/PR, email: gabriel.simepar@gmail.com

${ }^{2}$ Meteorological System of Paraná -(SIMEPAR), Curitiba/PR, email: cloviscechim.simepar@gmail.com

${ }_{3}^{3}$ Meteorological System of Paraná -(SIMEPAR),Curitiba/PR, email: giovani.simepar@gmail.com

${ }^{4}$ Meteorological System of Paraná -(SIMEPAR), Curitiba/PR, email:deppe@simepar.br
} 


\section{MULTITEMPORAL ANALYSIS OF SAR IMAGES FOR DETECTION OF FLOODED AREAS IN PANTANAL}

\section{INTRODUCTION}

The Pantanal is the world's largest continuous floodplain area and hosts a large concentration of wildlife. Flood and drought regime conditions the wildlife and influences vegetation dynamics. Also, the flood dynamics in this area affects the cattle ranching, an important economic activity in this area (PADOVANI, 2010).

The Pantanal is flooded by the Paraguay River and its tributaries every year in the rainy season due to its low altitude (ranging from $80 \mathrm{~m}$ to $150 \mathrm{~m}$ ) and low slopes (ANTUNES, ESQUERDO, 2014).

Understanding the dynamics of floods is of fundamental importance in inferring flood levels, as they cause drastic changes across the floodplain. Due to the great extent of the Pantanal and to the difficulty of access, satellite images become important tools for the analysis of floods, as they provide a synoptic view of the entire region.

In this work, it was made an analysis in Corumbá, state of Mato Grosso do Sul, and Cáceres, state of Mato Grosso, using data from rain gauges of INMET (Brazilian National Institute of Meteorology) to determine the flood and dry seasons and its seasonality in different years. Due to the lack of records of these rain gauges, it was opted for a spatial analysis using Remote Sensing data.

From Remote Sensing data it would be possible to analyze the precipitation through the Tropical Rainfall Measuring Mission (TRMM) and the GPM (Global Precipitation Measurement), which has its data provided by INPE (Brazilian National Institute of Space Research) as well as to monitor flooded areas, such as the use of multispectral or radar images.

Among the Remote Sensors used for the mapping of flood dynamics and seasonality the Synthetic Aperture Radar (SAR) type stands out because no influence of cloud cover is suffered. SAR images have been used in studies of flooded areas and in land use mapping in different regions, such as NOVO et al. (2002) and ZHOU et al. (2017).

An important satellite that has onboard SAR sensors is Sentinel 1. It is a constellation of 2 satellites, Sentinel $1 A$ (launched on April 3, 2014) and Sentinel 1B (launched on April 25, 2016). Both the Sentinel $1 \mathrm{~A}$ and Sentinel $1 \mathrm{~B}$ have similar characteristics, such as Polar orbit, sun synchronous, and an altitude of $693 \mathrm{~km}$. This Sentinel 1 constellation has a 6-day re-visit time, which allows for continuous environmental monitoring applications.

However, Remote Sensing data usually requires high storage and processing capacity, either via Geographic Information Systems (GIS) or programming languages, especially when historical series are used. However, a new platform for Remote Sensing data processing that stands out is Google Earth Engine. This platform combines a catalog of petabytes of multiple satellite images and geospatial data for planetary analysis and makes them freely available to scientists, researchers, and developers to detect changes, map trends, and quantify differences on Earth's surface. According to Gorelicket al. (2017), Google Earth Engine is a cloud-based platform for geospatial analysis on a planetary scale that brings Google's computing capabilities to handle a variety of high-impact social issues, including deforestation, drought, disasters, disease, food security, water management, climate monitoring, and environmental protection. In addition, the Google Earth Engine platform is an intrinsically parallel, highperformance computing service. It is accessed and controlled through an application programming interface (API) accessible by Internet browsers and by an interactive development environment (IDE) that enables the creation of prototypes and quick visualization of results.

Google Earth Engine is in use in a wide variety of disciplines, covering topics such as global forest change (HANSEN et al., 2013), global wetland change (PEKEL et al., 2016), crop yield estimation, rice mapping (DONG et al., 2016), urban mapping (ZHANG et al., 2015, PATEL et al., 2015), flood mapping (COLTIN et al., 2016), fire recovery (SOULARD et al., 2016), and malaria risk mapping (STURROCK et al., 2014). 
Also, Google Earth Engine has been integrated into a number of third-party applications, for example, analyzing the species habitat ranges (MAP OF LIFE, 2016), climate monitoring (CLIMATE ENGINE, 2016), and land use change assessment (COLLECT EARTH, 2016). A good example of a Brazilian application based on Google Earth Engine is MapBiomas (MAPBIOMAS, 2015), which aims to produce annual maps of land cover and land use in Brazil from 1985 to the present day and is the result of more than 20 organizations, including NGOs, universities, and companies.

In this way, the objective of this work was to demonstrate the possibility of using Remote Sensing images to identify the seasonality of floodable areas in the Pantanal region. More specifically, the main objective is to present that the use of a simple technique that is the band composition of processed SAR images can show the flood dynamics in the area. Sentinel 1 SAR data from years 2016, 2017, and 2018 as well as the Google Earth Engine platform were used in this work.

\section{MATERIALS AND METHODS}

The following methodology is proposed in order to contribute to the analysis of the seasonality of the flooding dynamics in the Pantanal biome in a spatialized way and using SAR images Sentinel 1.

The study area is presented in Figure 1. The study area comprises the states of Mato Grosso and Mato Grosso do Sul, in the Center West of Brazil, and advances over Bolivia, covering part of the area of the Pantanal biome (the Pantanal biome shape delimitation is from SILVA and ABDON, 1998).

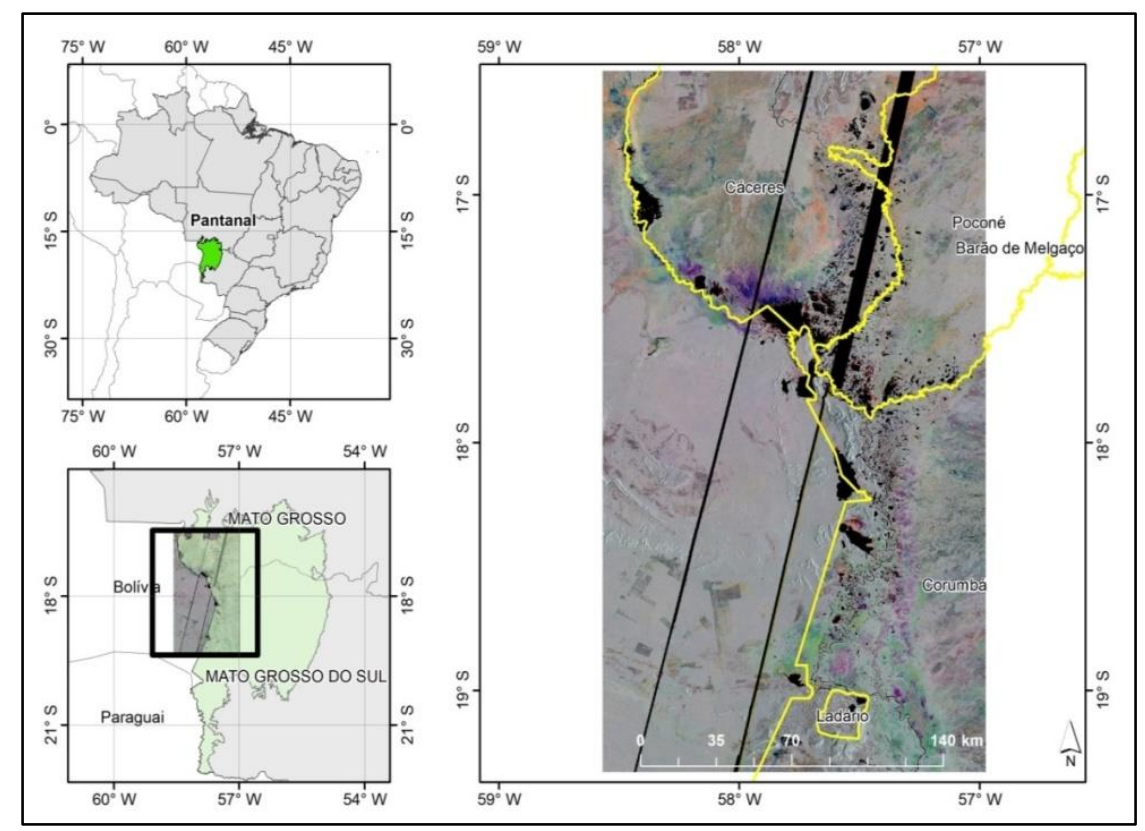

Figure 1 - Study Area.

Data from INMET Corumbá (state of Mato Grosso do Sul) and Cáceres (state of Mato Grosso) rain gauges were used. In order to suppress missing data these rain gauges the satellite product data 3B43 V6 from TRMM and GPM were also used. The TRMM and GPM data were acquired in the LAF Web portal (INPE), which is a tool for the instantaneous visualization of time series derived from satellite images (FREITAS et al., 2011). The TRMM pixel over Corumbá (state of Mato Grosso do Sul) rain gauges has a minimum area of approximately 0.25 degrees. The precipitation time series plot is formed by this 1 TRMM pixel over each rain gauge.

The SAR (Synthetic Aperture Radar - SAR) time series, including the Sentinel $1 \mathrm{~A}$ and $1 \mathrm{~B}$ satellites contain $10 \mathrm{~m}$ of spatial resolution and can reach 6 days of temporal resolution. They carry a $C$ 
band $(5.4 \mathrm{GHz})$ wavelength sensors, with horizontal and vertical ( $\mathrm{H}$ and $\mathrm{V})$ polarizations. For this study, it was prioritized the use of the composition VV (vertical transmission and reception).

Due to the large processing capacity of the Google Earth Engine platform, it was used a methodology that requires large processing effort to generate an RGB composition. Initially, all SAR Sentinel 1 data available on VV polarization for the years 2016, 2017 and 2018 were acquired. This represents a total of 1141 images in the study area $(215,449$, and 477 images for the years 2016, 2017, and 2018, respectively). For each pixel the mean value was generated per period. This average value per period was then associated with each RGB channel. The selected and arranged periods in each channel are presented in Table 1. Table 1 also shows the number of Sentinel 1 images available and used for each period and year.

Table 1 - Period and number of selected images associated with each band.

\begin{tabular}{ccccc}
\hline Channel & Months & $\mathbf{2 0 1 6}$ & $\mathbf{2 0 1 7}$ & $\mathbf{2 0 1 8}$ \\
\hline R & JanuarytoMarch & 48 & 141 & 155 \\
G & ApriltoSeptember & 52 & 190 & 198 \\
B & OctobertoDecember & 115 & 118 & 124 \\
\hline
\end{tabular}

The mean value of the SAR images for each pixel from January to March was calculated and assigned to the $R$ channel; from April to September for channel G; and from October to December to channel B. Table 1 also shows the number of Sentinel 1 images available and used for each period and year.

In this way, the hypothesis is that, as every year 2016, 2017 and 2018 may have presented a different flood or dry dynamic, keeping it constant during the months associated to each RGB channel will make it possible to highlight the dynamic in the area, since each RGB channel (or period of the year) will behave differently, resulting in different patterns evidenced in the images.

\section{RESULTS AND DISCUSSION}

\section{1 - Data analysis in the Pantanal of rain gauges and TRMM and GPM Satellites data}

A rainfall analysis was carried out at Corumbá (state of Mato Grosso do Sul - MS) (2 rain gauges) and Cáceres (state of Mato Grosso - MT) (1 rain gauge) for the years 2016, 2017, and 2018 to both observe and understand the inter and intra-annual cycle between flood and dry periods in the study area.

For the first rain gauges in Corumbá-MS (Figure 2), in some of the months between January and April 2017 and 2018 there was no record of precipitation. For the period from 2016 to 2018 it was observed that there was higher precipitation between January and March and November and January, which indicated a rainy period in the summer. The annual accumulated precipitation reached $952.4 \mathrm{~mm}$ in 2016, and the monthly average was $79.37 \mathrm{~mm}$.

For the second Corumbá-MS rain gauge, it can be observed that the months with the highest accumulated monthly precipitation occurred between January and March and October to December from 2016 to 2018. This also indicates that summer has greater precipitation. The annual accumulated precipitation was $838.8 \mathrm{~mm}$ in 2016, reaching $1515 \mathrm{~mm}$ in 2017 and $1066 \mathrm{~mm}$ in the year 2018, the monthly average was $69.9 \mathrm{~mm}$ in 2016, $126.25 \mathrm{~mm}$ in 2017, and $88.83 \mathrm{~mm}$ in 2018 (Figure 3). 
Figure 4 brings the results for TRMM and GPM over Corumbá-MS. The months of greatest precipitation were from January to May of 2016 and 2017. It reached $356 \mathrm{~mm}$ of maximum in January 2016.

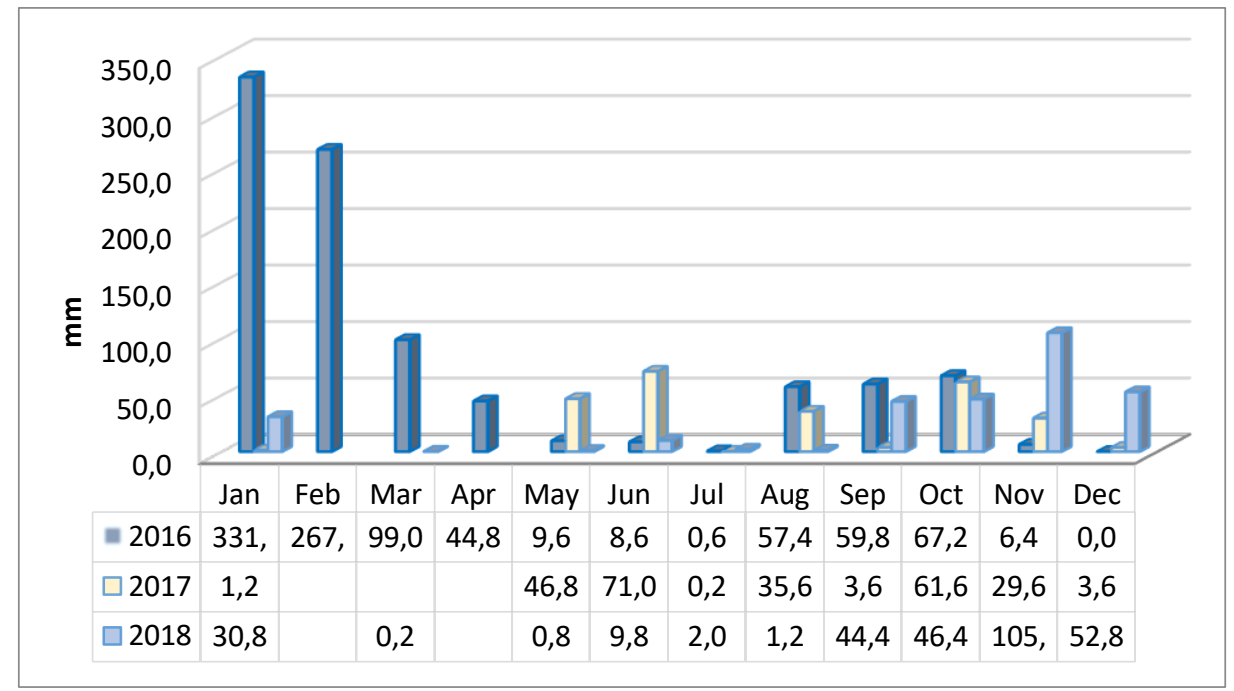

Figure 2 - Monthly cumulative precipitation (mm) INMET, Corumbá 1 - MS

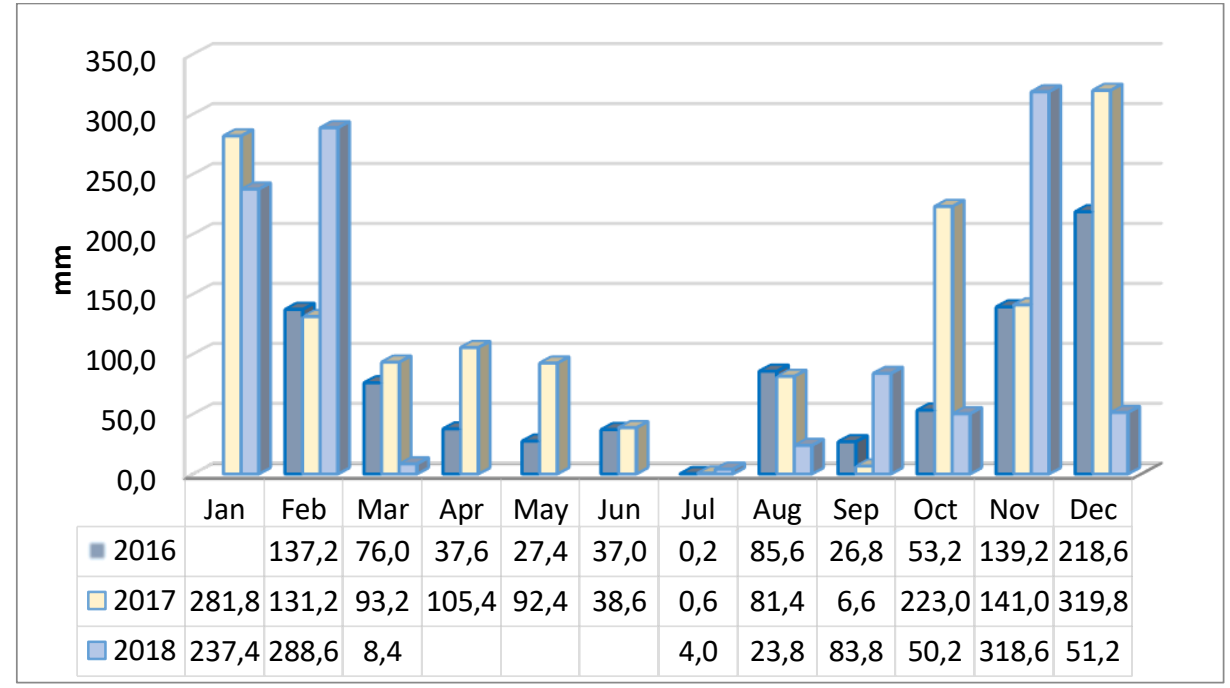

Figure 3 - Monthly cumulative precipitation (mm) IMNET, Corumbá 2 - MS 
PEREIRA, G. H. A., CECHIM JÚNIOR, C., FRONZA, G., DEPPE, F. A. C.

\section{MULTITEMPORAL ANALYSIS OF SAR IMAGES FOR DETECTION OF FLOODED AREAS IN PANTANAL}

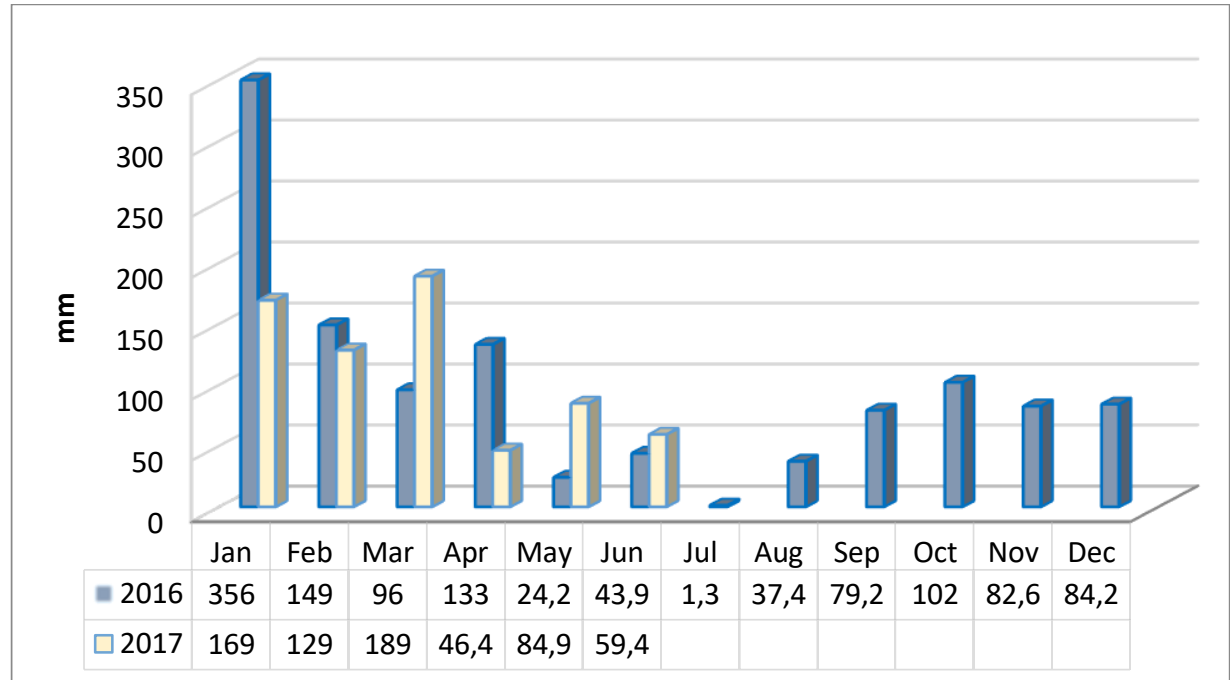

Figure 4 - Monthly cumulative precipitation TRMM and GPM $(\mathrm{mm})$, Corumbá-MS

At Cáceres-MT Rain Station a higher precipitation was obtained between October and December 2017 to 2018, with a total accumulated of $566.6 \mathrm{~mm}$ in 2017 and reaching $683.8 \mathrm{~mm}$ in 2018, with a monthly average of $47.22 \mathrm{~mm}$ in 2017 and of $56.98 \mathrm{~mm}$ in 2018. This indicates - and corroborating with Corumbá-MS - that the rainiest period occurred in the summer (Figure 5).

The Cáceres-MT had the most evident missing measurements data (Figure 5). Again, one can make use of TRMM and GPM data in an attempt to complement the missing data. The data from these periods can be seen in the TRMM and GPM accumulated precipitation plot, which indicates there was a greater precipitation between the months of January and March of each year (Figure 6).

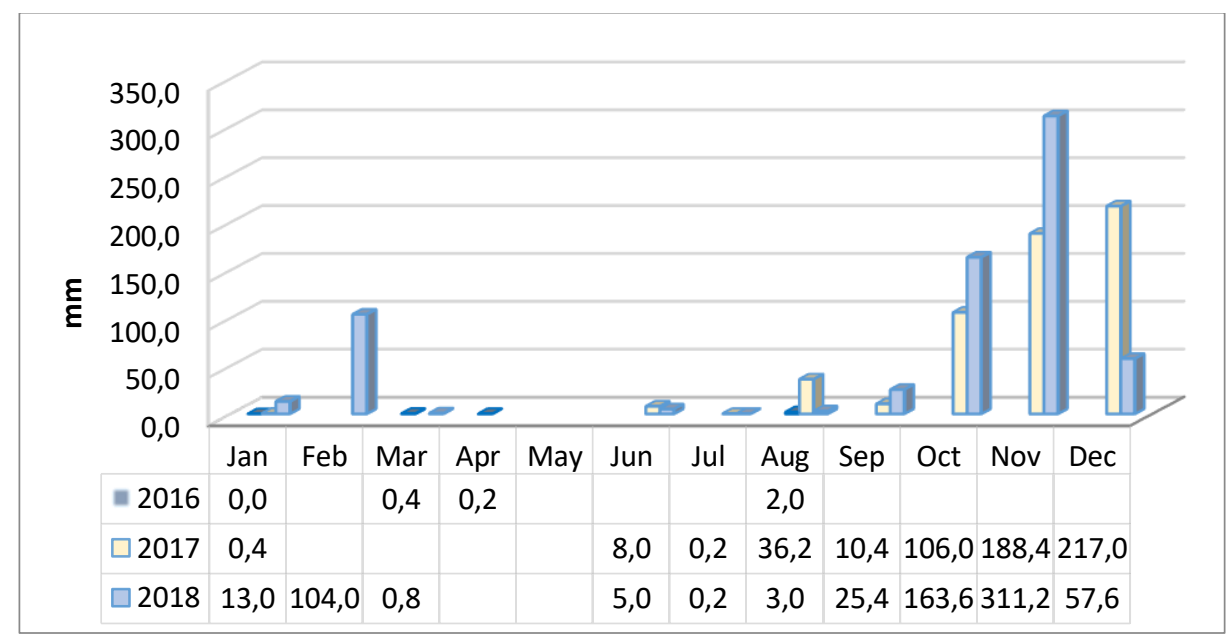

Figure 5 - Monthly cumulative precipitation (mm) INMET, Cáceres-MT 


\section{MULTITEMPORAL ANALYSIS OF SAR IMAGES FOR DETECTION OF FLOODED AREAS IN PANTANAL}

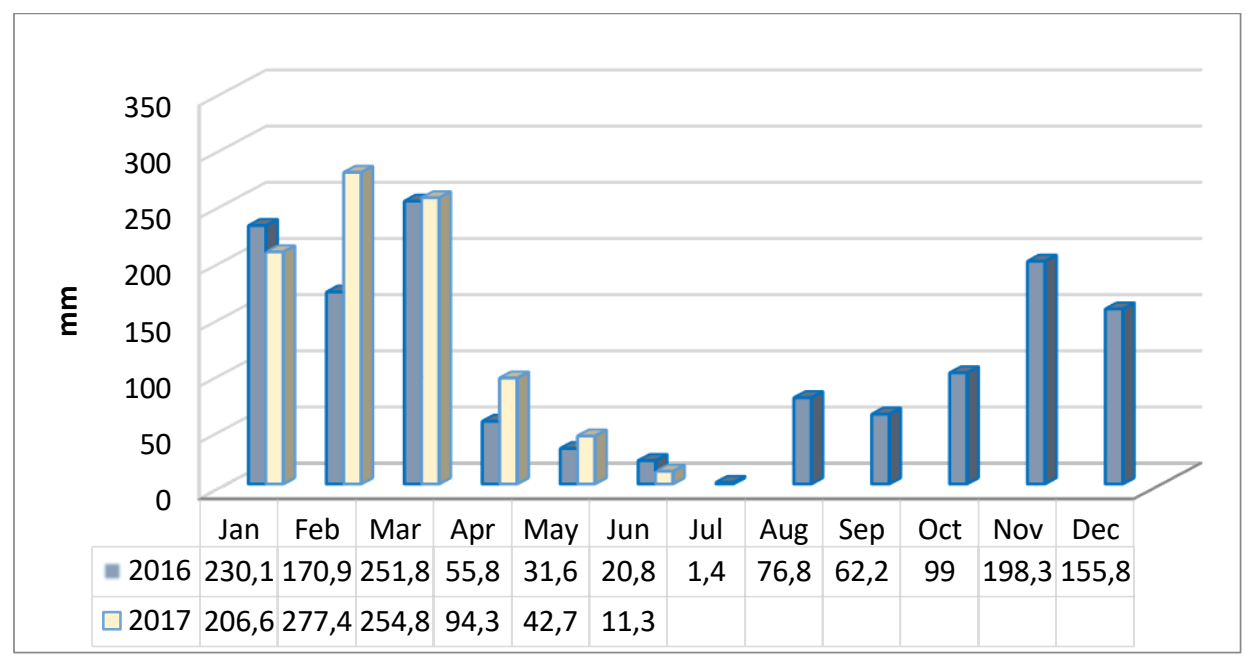

Figure 6 - Monthly cumulative precipitation TRMM and GPM (mm), Cáceres - MT

Nevertheless, the absence of rainfall data in these rain gauges is clear, which would compromise a deeper analysis and determination of flood and dry seasons. Thus, it is clear the lack of data and impossibility to analyze precisely the seasonal dynamics of precipitation as well as the determination of flood and drought intervals or severity in the Pantanal biome. Alternatively, it is possible to use other Remote Sensing data like imagery, such as Radar data.

\section{2 - Data Analysis for SAR Images of Pantanal}

The images resulted from the mean value per period associated to each channel of the RGB compositions for the years 2016, 2017 and 2018 are presented in Figure 7.
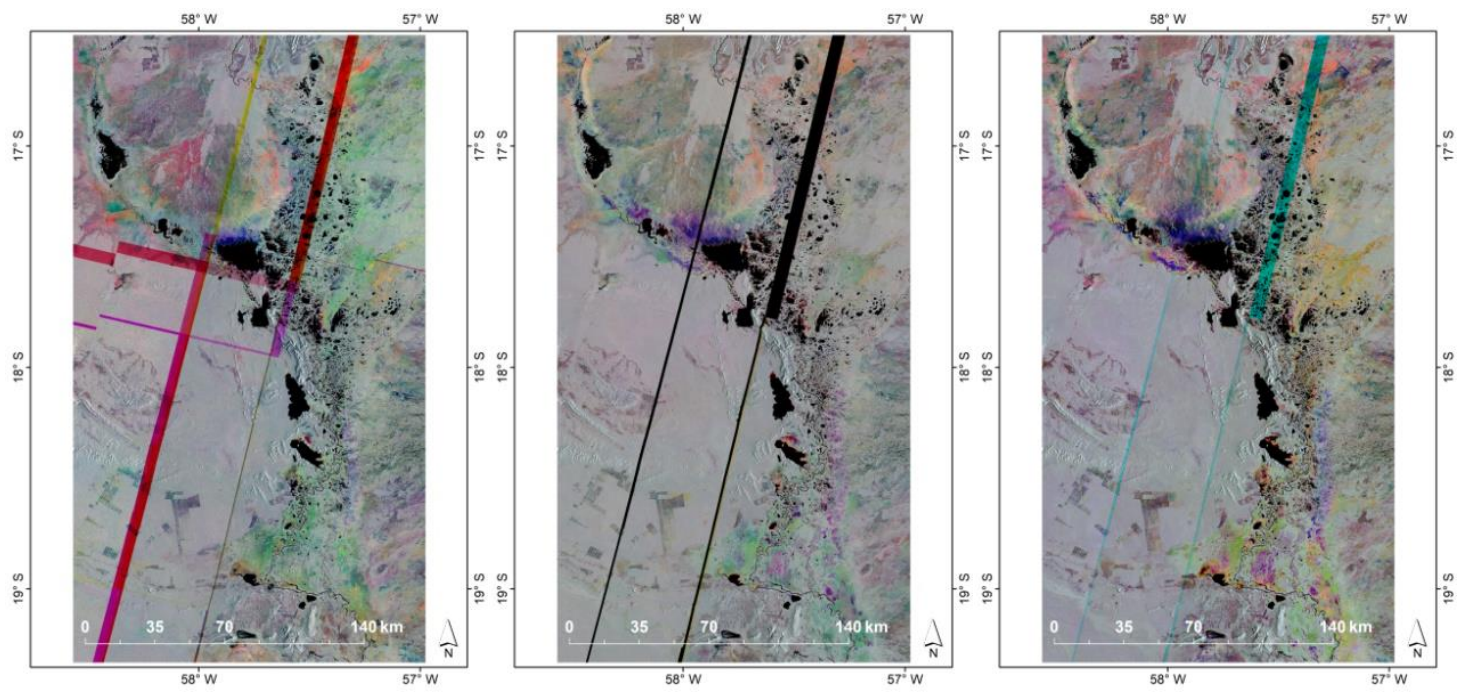

Figure 7 - Composed images results for SAR-Sentinel 1 data for the study area.
(A) Ano 2016
(B) Ano 2017
(C) Ano 2018

Initially, it is noticed that the distribution of colors and shades throughout each image in Figure 7 is different. Thus, the information variability and the mean value of each pixel per time of year associated to each RGB channel is demonstrated for the years 2016, 2017 and 2018 was different.

An important feature of SAR data is that there is usually no return of the sent energy from the water surface, since the sent pulse is normally reflected in another direction or absorbed. Sometimes this energy pulse can return to the sensor when reflected by ripples, suspended solids, or objects such as boats. 
Thus, it is possible to verify in the images that areas constantly flooded remained in black or very dark color, demonstrating absence or little information of return to the SAR sensor.

Grayscale areas demonstrate that RGB channels contain the same or very close values. That is, each period of the year in each RGB channel behaved in a similar way. Therefore, it does not show seasonal variations. These cases are expressed in Figure $8 \mathrm{a}$, where there was no change in the period and all RGB channels reacted in the same way, appearing in grayscale. It is only possible to discriminate the target according to the intensity of information backscattered to the SAR sensor, in which urban areas are more intense, water bodies have low return and vegetation in an intermediate scale.

And following the principles of remote sensing and band composition in the RGB channels, it is possible to highlight that areas in which the information may have undergone seasonal variation are presented in color scale. The reason is that if one channel has more information than another in the RGB composition, this channel will prevail over the others, highlighting the color of this channel. That is, areas submerged in a certain period of the year, will present dark tones in the RGB channel referring to this period, and the other channels will prevail.

If the area was submerged in 2 periods of the year, the third channel will prevail, as shown in Figure $8 \mathrm{~b}$. For example, as in the legend of Figure $8 \mathrm{~b}$, if the pixel shows blue color (the 3rd period related here to channel $B$ ), that means that this period had higher information (probably due to the presence of vegetation, which would cause greater backscattered information to the sensor), while the 1 st and 2 nd period ( $R$ and $G$ ) were submerged with lower response due to the presence of water.

As the results of this work are images derived from the band composition - and not from a classification process, these legends of Figure 8 are continuous and not only colored classes.

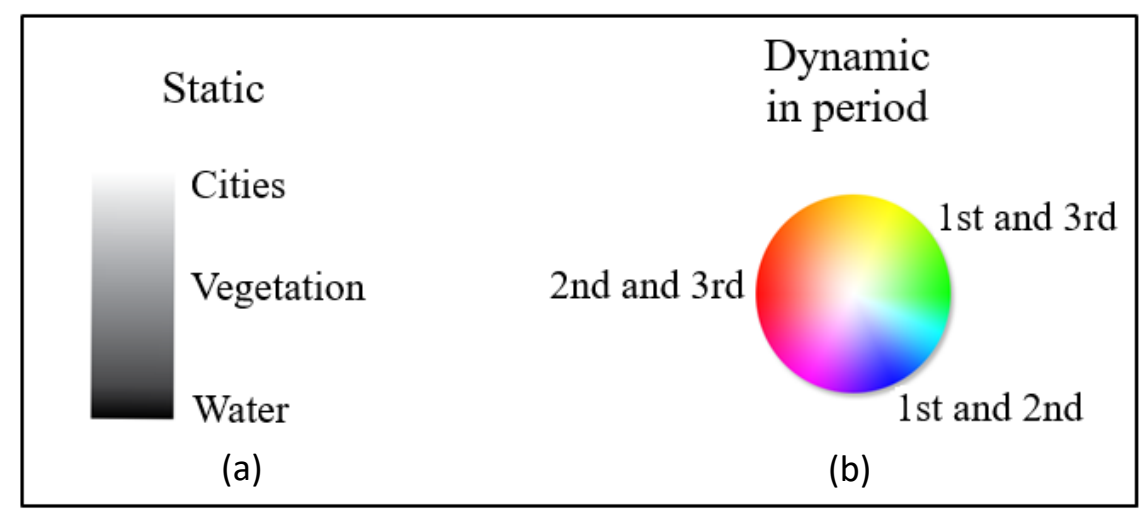

Figure 8 - Colors legend for identification of variation and seasonality of flooded areas according to the methodology presented in this work.

In order to better analyze the results, Figure 9 and Figure 10 are presented bringing regions of the study area. 


\section{MULTITEMPORAL ANALYSIS OF SAR IMAGES FOR DETECTION OF FLOODED AREAS IN PANTANAL}

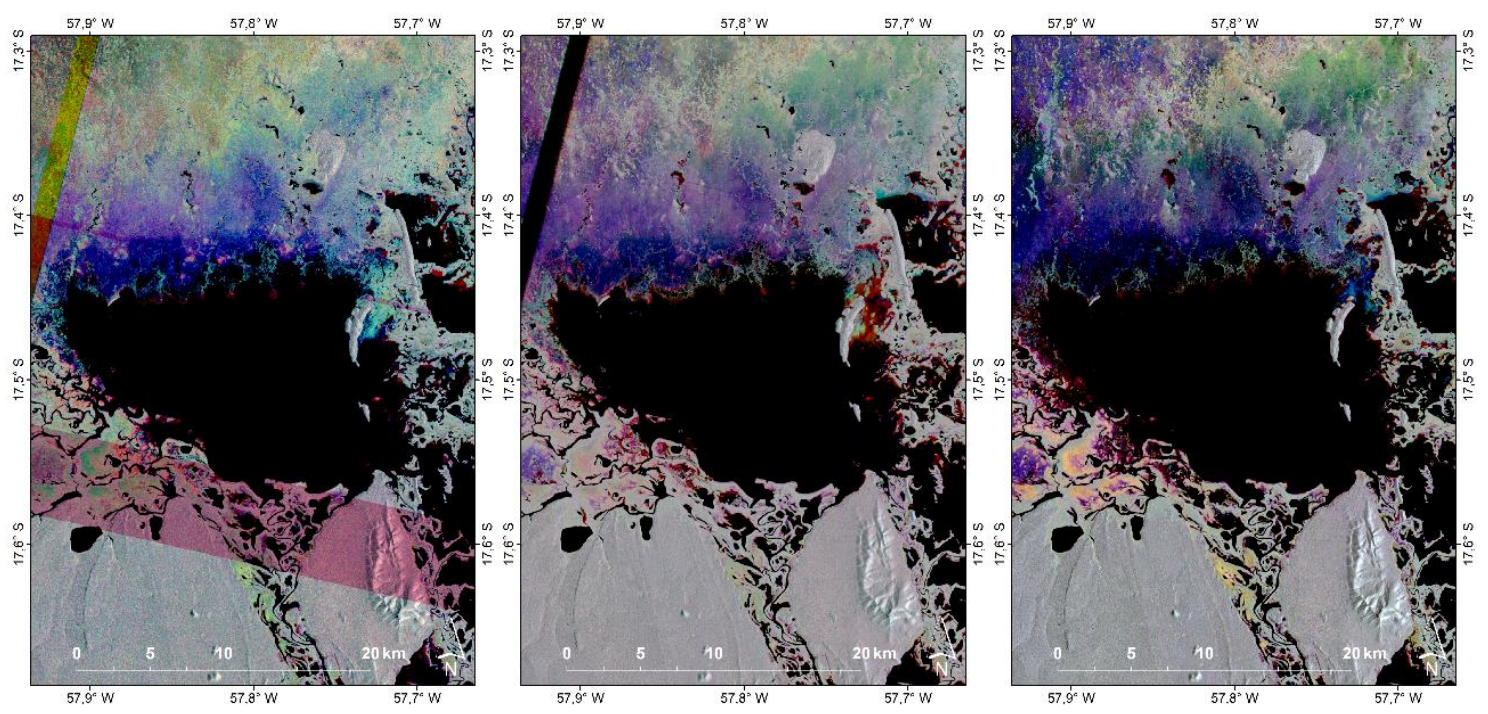

Figure 9 - Images' composition details from SAR-Sentinel 1.

(A) Ano 2016

(B) Ano 2017

(C) Ano 2018

Again, it is possible to constantly check dark areas, representing flooded areas throughout the year. Also, it is possible to verify the presence of large amount of areas in grayscale, which represents little variability of information in the RGB channels, that is, low seasonal variability.

However, it is noticed that there are also areas in colored tones distributed throughout the images, representing seasonal variations. This is because each RGB channel or combination thereof stands over the other channels demonstrating variations in the periods of the year associated with each RGB channel.

It is possible to highlight the color variation between the images of Figure 10, mainly in the north of the lagoon BaiaVermelha), indicated in (1). It is possible to verify that the pattern of flooding in this area was significantly different during the years 2016, 2017, and 2018. Also, besides the difference of shades and extensions indicated in (1), (2) and (3), it is possible to verify that greater extensions of area were constant flooded in 2018, presenting larger regions in dark shades in this year.

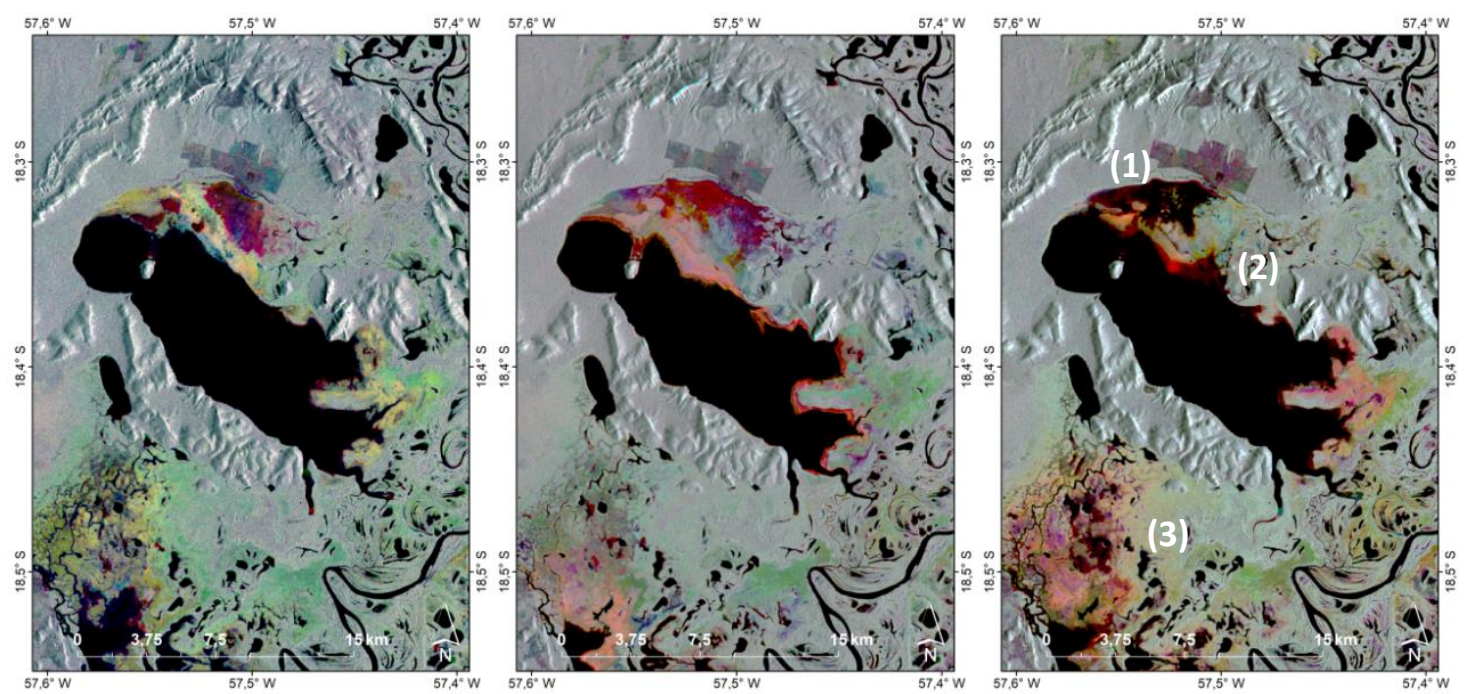

Figure 10 - Composition of the SAR images for BaiaVermelha.

(A) Ano 2016

(B) Ano 2017

(C) Ano 2018 
In order to compare these results with a reference data, Figure 11 presents the results obtained for each year with the GRWL data (Global River Widths from Landsat - ALLEN and PAVELSKY, 2018), highlighted in blue vector.

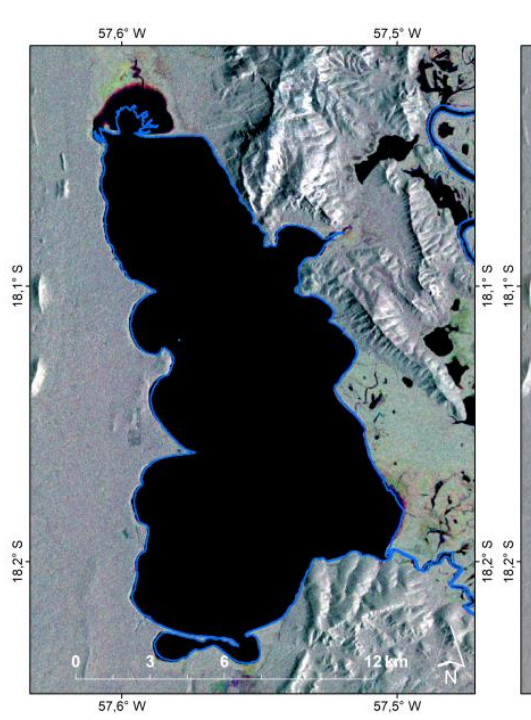

Figure 11 - Compari

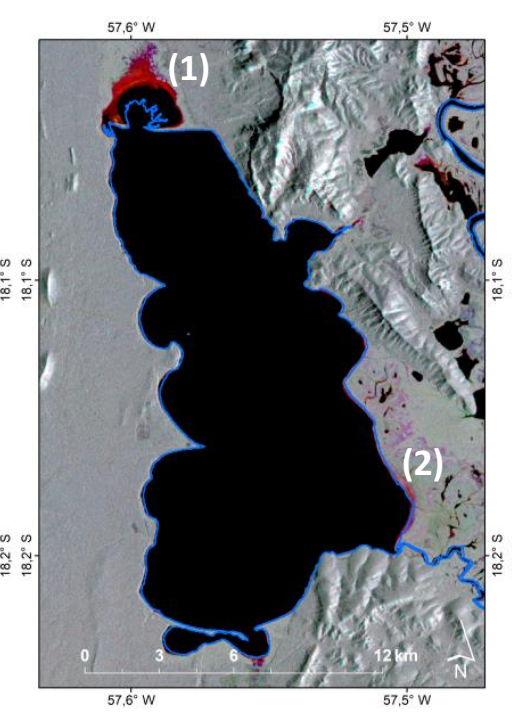

$57.6^{\circ} \mathrm{W}$

(A) 2016

(B) 2017

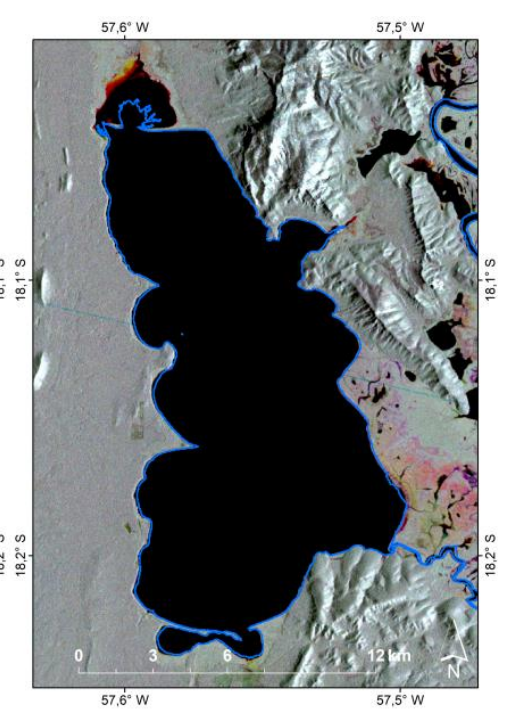

with GRWL data.

(C) 2018

Initially, it is highlighted the coherence between the GRWL mapping with the boundaries of the Mandioré lagoon. The dark areas, which represent areas constantly flooded in these periods, coincide with the limit of the GRWL mapping almost entirely.

However, in the north of Figure 11 marked as area (1), it is possible to observe that during the years 2016, 2017, and 2018 the area was constantly flooded (in a very dark shade - small response in all channels RGB). Also, this part was larger than that mapped by the GRWL reference.

In Figure 11b (2017 image), this region shows a reddish tone, that is, higher response of the $R$ channel, and consequently smaller of $G$ and $B$. This shows that for the months associated with $G$ and $B$ (April to September and October to December) that region was flooded.

Also, in a lesser extent, it is possible to highlight other areas where the GRWL and image boundaries demonstrate certain pond edge dynamics, which may have been flooded at some time of the year, as in the area indicated in (2) in Figure 11.

Although the main objective of the study was just to demonstrate the seasonality of wetland in Pantanal from the SAR Sentinel 1 via image processing and band compositions, a permanently flooded area quantitative was estimated. Table 2 shows the values in hectares of permanently flooded areas per year in the study area. 
PEREIRA, G. H. A., CECHIM JÚNIOR, C., FRONZA, G., DEPPE, F. A. C.

MULTITEMPORAL ANALYSIS OF SAR IMAGES FOR DETECTION OF FLOODED AREAS IN PANTANAL

Table 2 Annual quantitative flooded area analysis from SAR images

\begin{tabular}{ccc}
\hline Year & Area (ha) \\
\hline 2016 & $316,251.72$ \\
2017 & $306,241.99$ \\
2018 & $317,665.40$ \\
\hline
\end{tabular}

For example, it can be seen that the year 2018 was the period with the greatest flooded areas in Pantanal. This can be seen in the previously presented images, especially in Figure 10 and 11 . In these images it is possible to verify, even visually, that dark areas covered larger areas in the year 2018 than other years.

From the Water Reference Data (GRWL), the water covered area for this study area was $71,853.12$ ha. However, this data is based on a spatial resolution of $30 \mathrm{~m}$ (due the Landsat images), that is lower than the Sentinel1 SAR data. In this way, GRWL only maps pixels with areas equal or greater than $900 \mathrm{~m}^{2}$, and the methodology proposed in this work that can identify areas of up to $100 \mathrm{~m}^{2}$. Also, this GRWL base corresponds only to the rivers, including lakes and ponds that are in its bed, excluding isolated water bodies. And finally, GRWL is just for 1 base year, while here it is present results from 3 years.

According to Padovani (2010) and Paz (2011), traditional hydrological models, when isolated, do not serve as tools for forecasting and for the necessary responses to Pantanal flood. According to the weekly level of rivers in the Pantanal from September 2018 to March 2019, obtained from GeohidroPantanal at the Embrapa portal, in the rivers of Bela Vista do Norte, Porto São Francisco, Porto Alegre, Ladário, Porto Esperança, Forte Coimbra, and Porto Murtinho the period of highest level was September to December of 2018 and with increasing level from March to April of 2019 (PADOVANI et al., 2000). It is possible to say that such information from these authors is consistent with the one analyzed from the images resulting from this work.

\section{CONCLUSIONS}

The use of SAR images from the Sentinel 1 Satellites associated to the methodology proposed in this work allowed to analyze the flooded areas and their seasonality in the Pantanal for 2016, 2017, and 2018.

Because SAR images did not suffer atmospheric interferences, it was possible to obtain images from both rainy and dry seasons. This is of fundamental importance in this continuous monitoring of flooded areas, since the absence of information due to cloud cover at a specific season could be critical for the analysis of the seasonality of floods and droughts.

Also, through this methodology it is possible to avoid the problem of rainfall data analysis by rain gauges, which due to the lack of data may compromise the analysis.

And due to the processing capabilities of Google Earth Engine, it was possible to quickly process 1141 SAR images from the years 2016, 2017, and 2018, enabling faster identification, monitoring, and analysis of wetland dynamics, allowing easy implementation for other areas of study.

And finally, it was possible to identify that among the analyzed years, the year 2018 was the one that presented the greatest extensions of permanently flooded areas. It was possible to observe it in the Figures presented due larger dark shades images and also the quantitative mapping analysis. 


\section{REFERENCES}

ALLEN, G. H.; PAVELSKY, T. M. Global extent of rivers and streams.Science. Vol. 361, Issue 6402, pp. 585588. 2018. doi: https://doi.org/10.1126/science.aat0636

ANTUNES, J.F.F.; ESQUERDO, J.C.D.M. Classificação sub-pixel de séries temporais de dados MODIS para a quantificação de áreas inundadas do Pantanal. Anais 5o Simpósio de Geotecnologias no Pantanal, Campo Grande, MS. Embrapa Informática Agropecuária. 2014.

CLIMATE ENGINE, 2016.DesertResearchInstitute, Universityofldo.Disponível em: <http://climateengine.org>. Acessoem: $13 \mathrm{dez} .2018$.

COLLECT EARTH, 2016. United Nations Food and Agriculture Organization.Disponível em: <http://www.openforis.org/tools/collect-earth.html>.Acessoem: 13 dez. 2018.

COLTIN, B.; MCMICHAEL, S.; SMITH, T.; FONG, T. Automatic boosted flood mapping from satellite data.Int. J. Remote Sensing, 37 (5), p. 993-1015, 2016.

DONG, J.; XIAO, X.; MENARGUEZ, M.A.; ZHANG, G.; QIN, Y.; THAU, D.; BIRADAR, C.; Moore, B. Mapping paddy rice planting area in northeastern Asia with Landsat 8 images, phenology-based algorithm and Google Earth Engine. Remote Sensing Environment, v.185, p. 142-154, 2016.

FREITAS, R. M.; ARAI, E.; ADAMI, M.; SOUZA, A. F.; SATO, F. Y.; SHIMABUKURO, Y. E.; ROSA, R. R.; ANDERSON, L. O.; RUDORFF, B. F. T. Virtual laboratory of remote sensing time series: visualization of MODIS EVI2 data set over South America. Journal of Computational Interdisciplinary Sciences (2011) 2(1):57-68. doi: 10.6062/jcis.2011.02.01.0032.

GORELICK, N.; HANCHER, M.; DIXON, M.; ILYUSHCHENKO, S.; THAU, D.; MOORE, R. Google Earth Engine: Planetary-scale geospatial analysis for everyone. Remote Sensing of Environment, v. 202, p. 18-27, 2017.

HANSEN, M.C.; POTAPOV, P.V.; MOORE, R.; HANCHER, M.; TURUBANOVA, S.A.; TYUKAVINA, A.; THAU, D.; STEHMAN, S. V.; Goetz, S. J.; LOVELAND, T. R.; KOMMAREDDY, A.; EGOROV, A.; CHINI, L.; JUSTICE, C. O.; TOWNSHEND, J. R. G. High-resolution global maps of 21st-century forest cover change. Science, v.342, p. 850-853, 2013.

LOBELL, D.; THAU, D.; SEIFERT, C.; ENGLE, E.; LITTLE, B. A scalable satellite-based crop yield mapper. Remote SensingofEnvironment, v.164, p. 324-333, 2015.

MAPBIOMAS, 2015. MAPBIOMAS. Disponível em: <http://mapbiomas.org>. Acessoem: 22 jan. 2019.

MAP Of LIFE, 2016.Putting biodiversity on the map.Disponível em: <http://www.mol.org>. Acesso em: 13 dez. 2018. 
PEREIRA, G. H. A., CECHIM JÚNIOR, C., FRONZA, G., DEPPE, F. A. C.

\section{MULTITEMPORAL ANALYSIS OF SAR IMAGES FOR DETECTION OF FLOODED AREAS IN PANTANAL}

NOVO, E.L.M; COSTA, M.P.F. Fundamentos e aplicações de radar no estudo de áreas alagáveis. In: SOUZA, R. B. Oceanografia por Satélites, 2ed. Oficina de Textos, 2009, 382 p.

PADOVANI, C.R. Dinâmica Espaço-Temporal das Inundações do Pantanal. 174p. Tese (Doutorado em Ecologia Aplicada) - Escola Superior de Agricultura, Luiz de Queiroz, Piracicaba, SP, 2010.

PATEL, N.; ANGIULI, E.; GAMBA, P.; GAUGHAN, A.; LISINI, G.; STEVENS, F.; TATEM, A.; TRIANNI, A. Multitemporal settlement and population mapping from Landsat using google earth engine. Int. J. Appl. Earth Obs. Geoinf., v.35, p. 199-208, 2015.

PATEL, N; ESQUERDO, J. .D; MAIA, A.H.N; PAZIANOTTO, R.A.A; SORIANO, B.M.A. Geohidro-Pantanal, portal de informações hidrológicas da bacia do Alto Paraguai-Pantanal. 2000. Disponível: https://www.embrapa.br/pantanal/. Acesso em: 26 de março de 2019.

PAZ, A. R.; COLLISCHONN, W.; TUCCI, C. E. M.; PADOVANI, C. R. Large-scale modelling of channel flow and floodplain inundation dynamics and its application to the Pantanal (Brazil).Hydrological Processes, v. 25, p. 1498-1516, 2011.

PEKEL, J.F.; COTTAM, A.; GORELICK, N.; BELWARD, A.S. High-resolution mapping of global surface water and its long-term changes, Nature Geoscience, v. 540 (7633), p. 418-122, 2016.

SOULARD, C.E.; ALBANO, C.M.; VILLARREAL, M.L.; WALKER, J.J. Continuous 1985-2012 Landsat monitoring to assess fire effects on meadows in Yosemite National Park, California. Remote Sensing, v. 8 (5), p. 371, 2016.

STURROCK, H.J.; COHEN, J.M.; KEIL, P.; TATEM, A.J.; LE MENACH, A.; NTSHALINTSHALI, N.E.; HSIANG, M.S.; GOSLING, R.D. Fine-scale malaria risk mapping from routine aggregated case data. Malaria Journal, v.13 (1), p. 1-9, 2014.

ZHANG, Q.; LI, B.; THAU, D.; MOORE, R. Building a better urban picture: combining day and night remote sensing imagery. Remote Sensing, v.7 (9), p. 11887-11913, 2015.

ZHOU, T.; PAN, J.; ZHANG, P.; WEI, S.; HAN, T. Mapping winter wheat with multi-temporal SAR and optical images in an urban agricultural region. Sensors, v.17, p. 1-16, 2017. 